\title{
Article
}

\section{The Development and the Validation of a Novel Dissolution Method of Favipiravir Film-Coated Tablets}

\author{
Özge Göktuğ *(D, Ecem Altaş, Gönül Kayar and Mine Gökalp
}

check for

updates

Citation: Göktuğ, Ö.; Altaş, E.;

Kayar, G.; Gökalp, M. The

Development and the Validation of a

Novel Dissolution Method of

Favipiravir Film-Coated Tablets. Sci.

Pharm. 2022, 90, 3. https://doi.org/

10.3390/scipharm 90010003

Academic Editor: Jaehwi Lee

Received: 7 October 2021

Accepted: 10 November 2021

Published: 24 December 2021

Publisher's Note: MDPI stays neutral with regard to jurisdictional claims in published maps and institutional affiliations.

Copyright: (C) 2021 by the authors Licensee MDPI, Basel, Switzerland. This article is an open access article distributed under the terms and conditions of the Creative Commons Attribution (CC BY) license (https:// creativecommons.org/licenses/by/ $4.0 /)$.
Analytical Development Department of R\&D Center, Abdi Ibrahim Pharmaceuticals, Istanbul 34538, Turkey; altasecem.3@gmail.com (E.A.); gonul.kayar@abdiibrahim.com.tr (G.K.); mine.uz@abdiibrahim.com.tr (M.G.)

* Correspondence: ozge.goktug@abdiibrahim.com.tr; Tel.: +90-2126226850

\begin{abstract}
The aim of this study was to develop and validate a dissolution test for favipiravir release in a tablet dosage form using ultra-high performance liquid chromatography (UHPLC). The dissolution method was developed by testing the solubility of favipiravir in media with different $\mathrm{pH}$ values. The results demonstrated that the best dissolution was achieved in phosphate buffer with a $\mathrm{pH}$ of 6.8 . The amount of favipiravir that was released was about $100 \%$ after $30 \mathrm{~min}$. The UHPLC method presented linearity $(R=1.000)$ in the concentration range of $0.044-0.44 \mathrm{mg} / \mathrm{mL}$. The recovery parameter that was achieved ranged from $102.5 \%$ to $104.2 \%$. The system suitability, repeatability, and intermediate precision RSD \% results were found to be $0.36 \%, 1.99 \%$, and $2.49 \%$, respectively. In addition to these parameters and results, an F-test was performed using the Minitab 18 Statistical Software program for the intermediate precision and repeatability results. The standard and sample solutions were found to be stable for 2 days in their respective dissolution medium. This analytical method was also found to be selective for favipiravir. In conclusion, a simple and feasible dissolution method with a short run time of $2.5 \mathrm{~min}$ was developed and validated successfully. The obtained results demonstrated that the dissolution test developed here is adequate for its purpose and can be applied as the dissolution method for favipiravir in film-coated tablets for release analyses.
\end{abstract}

Keywords: favipiravir; dissolution test; solubility study; method development; validation

\section{Introduction}

COVID-19, also known by its full name, coronavirus 2019, is an infectious respiratory illness that affects many people, which is caused by Severe Acute Respiratory Syndrome Coronavirus 2 (SARS-CoV-2). First discovered in 2019 in Wuhan, China, the disease has spread worldwide since it was discovered, causing the COVID-19 pandemic [1]. A specific and effective drug against COVID-19 has not yet been discovered, and no specific drug has been approved for its treatment [2]. However, various antiviral drugs are being researched to treat COVID-19, and some are being used in clinical trials [3]. Some drugs have been shown to demonstrate a beneficial effect on the virus, such as oseltamivir, ivermectin, lopinavir, ritonavir, remdesivir, favipiravir, ribavirin, and chloroquine and hydroxychloroquine, and have been reported to show potential treatment effects against COVID-19 [4,5]. Specifically, favipiravir, which is an already approved drug to treat influenza in Japan, has been shown to have a positive effect, as have other drugs. According to some studies, it has been shown to have a healing effect that can be observed within a short time despite having severe side effects. Although it is not yet approved as the main anti-viral agent for COVID-19, favipiravir is considered a potential candidate drug [5,6]. In mid-February 2020, a clinical trial using favipiravir as therapy for COVID-19 was initiated and achieved promising results [7]. Recently, the treatment guidelines from many countries and some states in India have included favipiravir in their treatment protocols [8]. Over the past few months, clinical studies have been conducted around the world to evaluate the effectiveness of favipiravir for the management of COVID-19 [9]. 
As mentioned above, favipiravir is an anti-influenza drug that has shown large spectrum antiviral activity against a variety of other RNA viruses [10]. Favipiravir is an odorless powder that is white to light yellow in color, sparingly soluble in methanol and acetonitrile, and slightly soluble in water and ethanol. Favipiravir has the chemical structure depicted below, and it is chemically described as 6-fluoro-3-hydroxypyrazine2-carboxamine (Figure 1). The molecular weight of favipiravir is $157.10 \mathrm{~g} / \mathrm{mol}$, and its molecular formula is $\mathrm{C}_{5} \mathrm{H}_{4} \mathrm{FN}_{3} \mathrm{O}_{2}$.<smiles>NC(=O)c1nc(F)cnc1O</smiles>

Figure 1. Chemical structure of favipiravir.

The favipiravir molecule is marketed as under the brand name of Avigan Tablets $200 \mathrm{mg}^{\circledR}$, which are manufactured by Fujifilm Toyama Chemical Co., Ltd. (Tokyo, Japan) and have been used for the treatment of COVID-19. Dissolution is an important test in formulation development studies and is conducted in order to determine a drug's dosage for properties. Dissolution is an official test that is commonly used as a predictor of in vivo performance that is simulated to evaluate the performance of solid dosage forms, transdermal patches, and suspensions, and it is routinely used in quality control (QC) and research and development (R\&D) studies [11]. In the case of generic product development (Favipiravir $200 \mathrm{mg}$ Tablets) in the Abdi Ibrahim Research \& Development laboratory, these studies need to be performed for a comparison with the reference product (Avigan Tablets $\left.200 \mathrm{mg}^{\circledR}\right)$.

There are no studies in the literature providing information about the solubility and BCS information for favipiravir as an active substance. Therefore, the aim of this paper is to present a development and validation study for the dissolution test for film-coated tablets of favipiravir and an ultra-high performance liquid chromatography (UHPLC) method for the quantitation of the drug released from the dissolution test. This method has been validated to demonstrate that the test procedure is suitable for its intended purpose. Method validation will be based on validation parameters such as specificity, linearity and range, precision (system precision and method precision), accuracy, robustness, and solution stability. Validation was performed as per the International Conference on Harmonization (ICH) guidelines [12]. An F-test was performed using the Minitab 18 Statistical Software program for the intermediate precision and repeatability results.

\section{Materials and Methods}

\subsection{Materials, Reagents and Equipments}

Favipiravir reference standard (assigned purity, 99.9\%) was supplied from Optrix Laboratories Private Ltd. (Hyderabad, India). Favipiravir Film Coated-Tablets, containing $200 \mathrm{mg}$ of Favipiravir, were developed and produced in Abdi Ibrahim Research \& Development laboratory.

HPLC-grade acetonitrile was purchased from Merck (Darmstadt, Germany). Glacial acetic acid, potassium chloride, potassium dihydrogen phosphate, orto-phosphoric acid, sodium acetate anhydrous, boric acid, hydrochloric acid (37\%), and sodium hydroxide were Ph. Eur. reagent grade and purchased from Merck (Darmstat, Germany). Purified water was freshly prepared using Elga Purelab equipment (Buckinghamshire, England) for analytical measurements.

Acetate buffer with $\mathrm{pH} 4.5$, phosphate buffer (with $\mathrm{pH} 3.0, \mathrm{pH} 6.0$, and $\mathrm{pH}$ 6.8), borate buffer with $\mathrm{pH} 8.0$, and $0.1 \mathrm{~N} \mathrm{HCl}$ were prepared as per the USP and Ph. Eur. [13,14].

Kinetex EVO C18 column with a particle size of $1.7 \mu \mathrm{m}(100 \mathrm{~mm} \times 2.1 \mathrm{~mm})$ was purchased from Phenomenex Inc. (Aschaffenburg, Germany). 
Equipment and instruments used in the present study are: Seven Compact S210 model pH meter (Mettler-Toledo, Zurich, Switzerland), AX26DR and XP204 model analytical balance (Mettler-Toledo, Zurich, Switzerland), Transonic 890 model ultrasonic bath (Elma, Singen, Germany), WB14 model shaking water bath (Membert, Schwabach, Germany), Acquity model UHPLC system with binary solvent delivery pump, an autosampler, a photodiode array and ultraviolet detector (Waters Corporation, Milford, MA, USA), Cary 50 model UV spectrophotometer (Varian, Cary, NC, USA) and VK 7010 model dissolution equipment (Varian, Cary, NC, USA). Waters Empower 3 software (Waters Corporation, Milford, MA, USA) was used for data acquisition and processing.

\subsection{Methods}

\subsubsection{Filter Compatibility}

The function of the filter is the removal of particles from sample solutions that are insoluble and may cause turbidity. The evaluation of the filter must be performed to control whether the active substance is adsorbed by the filter or not [15]. In this study, filter compatibility was evaluated using different filters, i.e., $0.45 \mu \mathrm{m} \mathrm{RC,} 0.45 \mu \mathrm{m}$ PTFE, $0.45 \mu \mathrm{m}$ PVDF, and $0.45 \mu \mathrm{m}$ Nylon. Standard solutions were prepared in dissolution media with different $\mathrm{pH}$ values, with a final concentration of $0.222 \mathrm{mg} / \mathrm{mL}$, and the solutions were filtered through $0.45 \mu \mathrm{m}$ RC filter, $0.45 \mu \mathrm{m}$ PTFE filter, $0.45 \mu \mathrm{m}$ PVDF filter and $0.45 \mu \mathrm{m}$ Nylon filter. Unfiltered and filtered standard solutions were injected, and chromatograms were observed.

\subsubsection{Solubility Determination}

In the early stages of dissolution method development studies, it was important to select the most appropriate dissolution media in order to evaluate the performance of the dosage form. Therefore, solubility data were used as the basis for the selection of the dissolution media for favipiravir.

For favipiravir solubility, the value of the product corresponding to the highest therapeutic dose $(1600 \mathrm{mg})$ taken at one time was studied in $250 \mathrm{~mL}$ beakers containing different media [16].

Since the expected solubility values could not be obtained in solubility studies at this concentration $(1600 \mathrm{mg} / 250 \mathrm{~mL})$, solubility studies have been carried out with $200 \mathrm{mg}$ (maximum strength dose) in different media, such as distilled water, acetate buffer with $\mathrm{pH}$ 4.5, phosphate buffer with $\mathrm{pH}$ 3.0, phosphate buffer with $\mathrm{pH}$ 6.0, phosphate buffer with 6.8, borate buffer with $\mathrm{pH} 8.0$, and $0.1 \mathrm{~N} \mathrm{HCl}$ as per the European Medicines Agency (EMA) [17]. The samples were shaken in a shaking water bath at $37.0 \pm 0.5^{\circ} \mathrm{C}$ for $24 \mathrm{~h}$. After $24 \mathrm{~h}$, the samples were taken from the shaking water bath and diluted with relevant dissolution media at a final concentration of $0.222 \mathrm{mg} / \mathrm{mL}$, then filtered and injected into the LC system. The solubility\% value of the samples was calculated with a linearity equation, as depicted in Equation (1). Solubility and dissolution\% calculations were determined using the following Equations (2) and (3):

$$
\begin{gathered}
y=a x+b \\
\text { Solubility }(\mathrm{mg} / \mathrm{mL})=\frac{A_{\text {Sam }-b}}{a} \times S \times 100 \\
\text { Dissolution } \%=\frac{A_{\text {Sam }-b}}{a} \times \frac{250}{W_{\text {Sam }}} \times S \times 100
\end{gathered}
$$

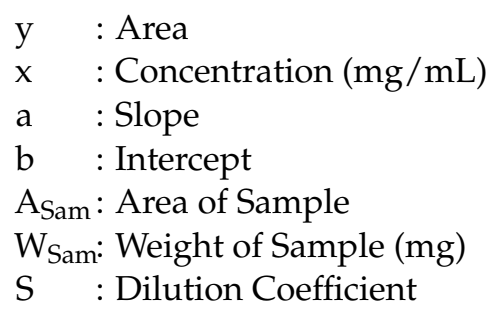


The dose solubility ratio is calculated as follows: highest single therapeutic dose (mg) divided by solubility $(\mathrm{mg} / \mathrm{mL})$. Dose $(\mathrm{mg}) /$ Solubility $(\mathrm{mg} / \mathrm{mL})=$ Dosage Volume $(\mathrm{mL})$. An active substance is considered highly soluble when Dosage Volume is $250 \mathrm{~mL}$ or less [18].

\subsubsection{Selection of Dissolution Volume, Stirring Rate and Apparatus}

The theoretical solubility condition value of favipiravir was evaluated with different dissolution volumes. Solubility data obtained from the above calculation were taken as the basis for the selection of a dissolution volume for favipiravir.

The apparatus and stirring rate were determined as per EMA and FDA guidelines [19,20].

\subsubsection{Dissolution Method Development and Determination of $\lambda_{\max }$}

After determining the most suitable dissolution medium, the standard solution at $100 \%$ concentration $(0.222 \mathrm{mg} / \mathrm{mL})$ was scanned in the range of $190-400 \mathrm{~nm}$ in $1.0 \mathrm{~cm}$ quartz cell, and spectra were recorded to determine the $\lambda_{\max }$ of the active substance.

\subsubsection{Dissolution Test Chromatographic Conditions}

The Waters Acquity UHPLC system was utilized for the analysis. Analytical method development and validation were performed on Phenomenex Kinetex EVO C18, $2.1 \times 100 \mathrm{~mm}$, $1.7 \mu \mathrm{m}$ stationary phase (Aschaffenburg, Germany). The analysis was carried out in a column with an oven temperature of $35^{\circ} \mathrm{C}$, and the sample temperature was maintained at $25{ }^{\circ} \mathrm{C}$ with isocratic conditions using a mobile phase consisting of a mixture of the buffer solution with pH 2.5 and acetonitrile in the ratio 80:20 (v:v). The mobile phase was filtered with $0.2 \mu \mathrm{m}$ Millipore membrane filter and degassed by sonication. The mobile phase was run at a flow rate of $0.4 \mathrm{~mL} / \mathrm{min}$. The injection volume was $1 \mu \mathrm{L}$ for the blank, standard, and sample solutions. The total chromatographic run time was $2.5 \mathrm{~min}$. Before initiating the analysis, every standard and sample were filtered through $0.22 \mu \mathrm{m}$ RC filter, and the analysis was monitored at $225 \mathrm{~nm}$.

Preparation of Buffer Solution with $\mathrm{pH}$ 2.5: In $1000 \mathrm{~mL}$ purified water, $1.36 \mathrm{~g}$ of potassium dihydrogen phosphate was dissolved. After dissolving the buffer solution, $\mathrm{pH}$ was adjusted to $2.5 \pm 0.05$ with diluted orto-phosphoric acid.

Preparation of Standard Solution ( $\left.\mathrm{C}_{\text {Favipiravir: }}: 0.222 \mathrm{mg} / \mathrm{mL}\right)$ : First, $22.2 \mathrm{mg}$ of favipiravir reference standard was weighed into a $100 \mathrm{~mL}$ volumetric flask. Afterwards, $5 \mathrm{~mL}$ of acetonitrile was added and sonicated for $10 \mathrm{~min}$ to dissolve and diluted to volume with dissolution media. It was filtered through $0.22 \mu \mathrm{m} \mathrm{RC}$ filter and transferred to vial.

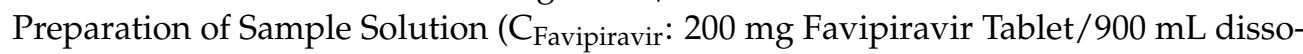
lution media: $0.222 \mathrm{mg} / \mathrm{mL}$ ): Dissolution testing was performed in compliance with USP 30 [21] using paddles (apparatus II) at $50 \mathrm{rpm}$, and the bath temperature was maintained at $37.0 \pm 0.5^{\circ} \mathrm{C}$. Nine hundred milliliters of phosphate buffer with $\mathrm{pH} 6.8$ solution, which needed to be freshly prepared, was used as the dissolution medium. Dissolution samples were collected at 30th minutes due to the highly soluble nature of favipiravir. Samples aliquots were filtered through a $0.22 \mu \mathrm{m} \mathrm{RC}$ filter and analyzed by UHPLC. The cumulative dissolution \% was calculated using a standard calibration curve.

\subsubsection{Dissolution Method Validation}

The proposed development method was validated with specificity, linearity and range, system precision, method precision (repeatability and intermediate precision), accuracy, robustness, and solution stability parameters in accordance with the ICH guidelines- [12].

\section{Specificity}

The specificity test is the ability of the method to measure the analyte response in the presence of other substances or those that are expected to be present. Specificity was examined by analyzing blank (dissolution medium), placebo, standard, and sample solutions. The placebo solution consists of all the excipients (povidone K30, colloidal silicon dioxide, crospovidone CL, sodium starch glycolate type-A vivastar, sodium stearyl 
fumarate, and opadry 03A42214 yellow) without the favipiravir active substance. The overlay of blank, placebo, standard, and sample chromatograms were recorded. There could not be any peaks at the retention time of the favipiravir peak from the blank and placebo solutions in chromatograms of standard and sample solutions. The spectrum of the favipiravir peak in the chromatogram obtained from standard and sample solutions could have no interference with other peaks. The purity angle of the favipiravir peak could be less than the purity threshold in chromatograms of standard and sample solutions.

Linearity and Range

The linearity of an analytical method is its ability to elicit test results that are proportional to the concentration of analytes in the samples within a given range. The linearity plot was constructed for favipiravir in the concentration range from $20 \%$ to $200 \%$ of the standard concentration $(0.222 \mathrm{mg} / \mathrm{mL})$. The appropriate dilutions were made from favipiravir stock standard solution prepared in order to achieve 6 different concentrations. The calibration curve was plotted as the concentration of the respective drug solutions versus the peak area at each level. The slope, $y$-intercept, and correlation coefficient (R) were determined. The correlation coefficient between concentration and areas should not be less than 0.99 .

\section{System Precision}

System suitability ensures the quality of the method for the accuracy of the results. To determine the system suitability standard solution is prepared at $100 \%$ concentration and injected six times. The average, SD, and RSD\% for the peak area of favipiravir were calculated. The RSD\% of peak areas should be less than $2.0 \%$, theoretical plate count of peaks should be greater than 2000, and symmetry factor of peaks should be within 0.8-1.5.

\section{Method Precision-Repeatability}

The repeatability parameter is performed with an optimized dissolution test on six tablets. The precision of the method was demonstrated by calculating RSD\% of release $\%$ for six measurements. The RSD\% of sample results should be less than $5.0 \%$.

\section{Method Precision-Intermediate Precision}

The intermediate precision of the method is verified by conducting the precision study using different instruments, different columns of the same make, by different analysts on different days under the same experimental conditions. Six samples from the same batch were prepared and analyzed by the proposed method. The RSD\% of sample results between repeatability and intermediate precision parameters should be less than $5.0 \%$.

F-test was performed using the Minitab 18 Statistical Software program for the comparison of the results between repeatability and intermediate precision. The F-distribution was developed by Fisher in order to test the equality of the average values and compare the precision of the measurements. If the $p$-value is less than or equal to the specified significance level alpha, the null hypothesis is rejected; otherwise, the null hypothesis is not rejected. Hence, variances are considered equal [22].

\section{Accuracy}

The average recovery\% of favipiravir is calculated to represent the accuracy of the method. The accuracy of the proposed method was further assessed by recovery studies at different concentration levels by the standard addition method. The recovery studies were performed at three different levels-10\%,100\%, and 120\%—of working-level concentration. At each level, three determinations were performed. The recovery $\%$ was calculated from the experimental and theoretical amounts. The overall RSD \% of samples results should be less than $2.0 \%$. 


\section{Robustness}

The robustness is the ability of an analytical method to remain unaffected by making small variations in method parameters such as wavelength $( \pm 2 \mathrm{~nm})$, flow rate $( \pm 0.1 \mathrm{~mL} / \mathrm{min})$, column temperature $\left( \pm 2{ }^{\circ} \mathrm{C}\right)$ and stirring rate $( \pm 5 \mathrm{rpm})$. The chromatographic parameters like retention time, symmetry factor, theoretical plate count and release $\%$ were recorded, and the results were reported.

\section{Solutions Stability}

Standard and sample solutions were stored at room temperature $\left(25^{\circ} \mathrm{C}\right)$ and were analyzed by UHPLC for $48 \mathrm{~h}$ at specified time intervals to evaluate solution stability in the optimized dissolution medium. The standard and sample solutions are stable until the range similarity of $98.0-102.0 \%$ value.

\section{Results and Discussion}

\subsection{Filter Compatibility}

The compatibility of $0.45 \mu \mathrm{m}$ RC filter, $0.45 \mu \mathrm{m}$ PTFE filter, $0.45 \mu \mathrm{m}$ PVDF filter and $0.45 \mu \mathrm{m}$ Nylon filter was studied. Standard solutions were filtered and analyzed. The similarity\% results of peak areas between unfiltered and filtered standard solutions were calculated and tabulated in Table 1. The results were evaluated, and a $0.45 \mu \mathrm{m}$ RC filter was found suitable for filtration because of the fact that the best performance in all results was obtained from a $0.45 \mu \mathrm{m}$ RC filter, and it is widely used and less costly [15,23].

Table 1. Filter Selection: Area Similarity\% Results for Favipiravir Standard Solution.

\begin{tabular}{|c|c|c|c|c|c|}
\hline \multicolumn{6}{|l|}{ Filter } \\
\hline Media & Unfiltered & $\begin{array}{c}0.45 \mu \mathrm{m} \\
\mathrm{RC}\end{array}$ & $\begin{array}{c}0.45 \mu \mathrm{m} \\
\text { PTFE }\end{array}$ & $\begin{array}{c}0.45 \mu \mathrm{m} \\
\text { PVDF }\end{array}$ & $\begin{array}{c}0.45 \mu \mathrm{m} \\
\text { Nylon }\end{array}$ \\
\hline $0.1 \mathrm{~N} \mathrm{HCl}$ & - & 100.6 & 101.2 & 101.1 & 101.6 \\
\hline Phosphate Buffer with pH 3.0 & - & 100.4 & 100.4 & 100.4 & 100.3 \\
\hline Acetate Buffer with pH 4.5 & - & 100.0 & 97.3 & 97.3 & 97.6 \\
\hline Phosphate Buffer with pH 6.0 & - & 97.5 & 97.9 & 98.0 & 98.5 \\
\hline Phosphate Buffer with pH 6.8 & - & 100.4 & 100.7 & 101.4 & 101.8 \\
\hline Distilled Water & - & 100.4 & 100.7 & 101.5 & 102.0 \\
\hline Borate Buffer with $\mathrm{pH} 8.0$ & - & 100.0 & 101.4 & 101.6 & 102.1 \\
\hline
\end{tabular}

\subsection{Solubility Determination}

The solubility results of favipiravir in different proposed dissolution media were summarized in Table 2 . The data have been demonstrated that favipiravir has low solubility in $0.1 \mathrm{~N} \mathrm{HCl}$ and phosphate buffer with $\mathrm{pH} 3.0$ media since the dosage volume is higher than $250 \mathrm{~mL}$. Favipiravir active substance is highly soluble in acetate buffer with pH 4.5, phosphate buffer with $\mathrm{pH}$ 6.0, phosphate buffer with $\mathrm{pH} 6.8$, distilled water and borate buffer with pH 8.0 media since its dosage volume is less than $250 \mathrm{~mL}$.

Table 2. Solubility results of favipiravir in different proposed dissolution media.

\begin{tabular}{ccc}
\hline Test Media & Dosage Volume $(\mathbf{m L})$ & Solubility $(\mathbf{m g} / \mathbf{m L})^{\mathbf{1}}$ \\
\hline 0.1 N HCl & 380 & 0.526 \\
Phosphate Buffer with pH 3.0 & 290 & 0.689 \\
Phosphate Buffer with pH 6.8 & $\mathbf{2 4 5}$ & 0.815 \\
Acetate Buffer with pH 4.5 & $\mathbf{2 4 4}$ & 0.818 \\
Distilled Water & $\mathbf{2 4 3}$ & 0.822 \\
Borate Buffer with pH 8.0 & $\mathbf{2 3 3}$ & 0.858 \\
Phosphate Buffer with pH 6.0 & $\mathbf{2 3 2}$ & 0.862 \\
\hline
\end{tabular}

\footnotetext{
1 Average of 3 determinations.
} 
As per the solubility results of favipiravir in different dissolution media in Table 2, distilled water media was not selected because of the fact that the conductivity and $\mathrm{pH}$ value are variable. Phosphate buffer with $\mathrm{pH} 6.0$ and borate buffer with $\mathrm{pH} 8.0$ do not reflect the physiological medium recommended in EMA [17]; thus, those media were not selected as the dissolution medium. Acetate buffer with $\mathrm{pH} 4.5$ medium has a close $\mathrm{pH}$ value to the $\mathrm{pKa}$ value of favipiravir, and the reference product's dissolution results did not reach $100 \%$ value for acetate buffer with $\mathrm{pH} 4.5$ medium. The most suitable physiological medium for the solubility study was found as phosphate buffer with $\mathrm{pH} 6.8$. Therefore, phosphate buffer with $\mathrm{pH} 6.8$ was chosen as the dissolution medium.

\subsection{Selection of Dissolution Volume}

According to the solubility results of favipiravir in different dissolution volumes in Figure 2, the sink conditions for favipiravir active substance in $500 \mathrm{~mL}$ volume could not be provided when the above-mentioned results of the sink studies in various solutions with different $\mathrm{pH}$ values were evaluated. However, the sink conditions were provided for favipiravir active substance in $900 \mathrm{~mL}$ volume, acetate buffer with $\mathrm{pH} 4.5$, distilled water, phosphate buffer with $\mathrm{pH}$ 6.0, phosphate buffer with $\mathrm{pH} 6.8$, and borate buffer pH 8.0 media. For this reason, $900 \mathrm{~mL}$ volume was selected for dissolution test analyses.

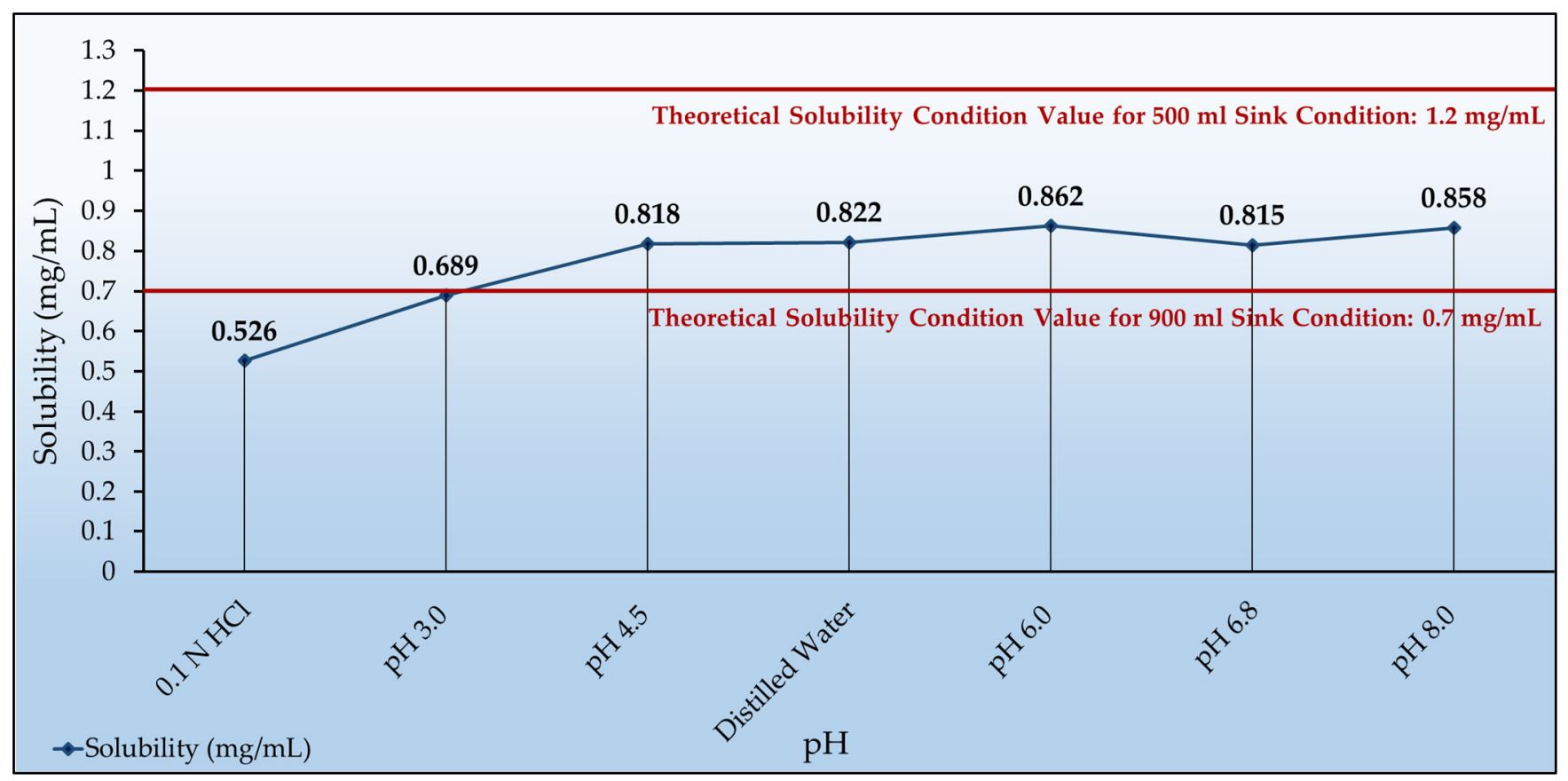

Figure 2. Graphical presentation of solubility versus $\mathrm{pH}$ of favipiravir in different media and in different dissolution volumes.

\subsection{Selection of Stirring Rate and Apparatus}

EMA and FDA guidelines [19,20] recommended that analytical method development for dissolution studies should be initiated at the speed of $50 \mathrm{rpm}$ with the paddle apparatus due to mild agitation conditions. Therefore, $50 \mathrm{rpm}$ was chosen as the stirring rate for this study.

\subsection{Dissolution Method Development and Determination of $\lambda_{\max }$}

The standard solution was scanned in the range of $190-400 \mathrm{~nm}$ in a $1.0 \mathrm{~cm}$ quartz cell against phosphate buffer with $\mathrm{pH}$ 6.8. The UV absorption spectrum of favipiravir shows absorbance peak at $225 \mathrm{~nm}$ (Figure 3). 


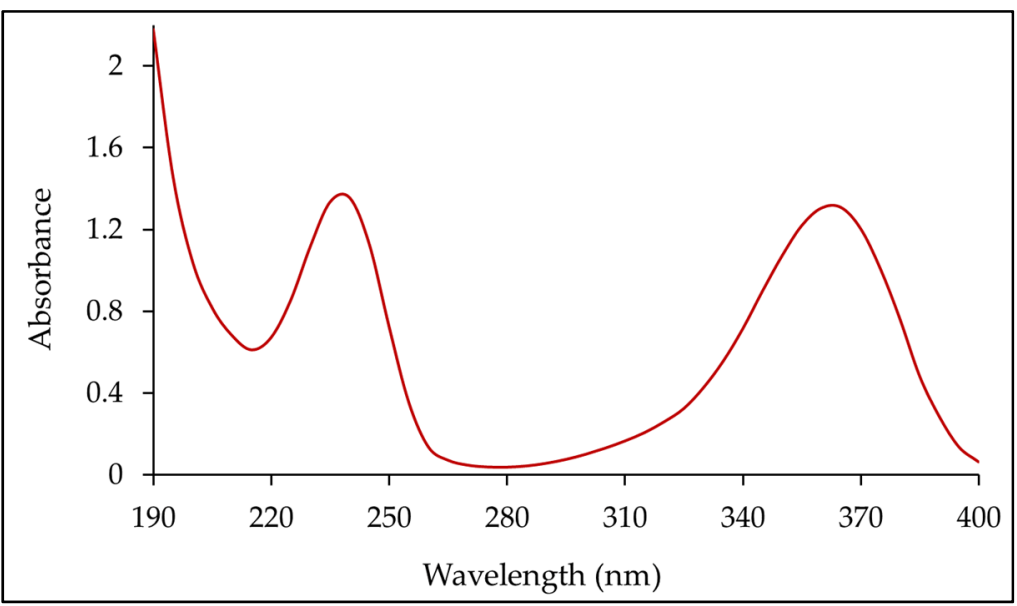

Figure 3. UV-Vis spectrum of favipiravir.

The dissolution medium was selected based on the solubility studies. The following dissolution conditions were preferred, and the used analytical method was the UHPLC method. After selecting the best conditions, the validation of the chromatographic method was performed.

\subsection{Dissolution Method Validation \\ 3.6.1. Selectivity}

The specificity of the method was established by injecting blank (dissolution medium), placebo, standard, and sample solutions individually to examine any interference. There are no peaks at the retention time of the favipiravir peak from blank and placebo solutions in chromatograms of standard and sample solutions. The spectrum of the favipiravir peak in chromatograms obtained from standard and sample solutions has no interference with other peaks. The purity angle of the favipiravir peak is found less than the purity threshold in chromatograms of standard and sample solutions. Therefore, the specificity of the method has been proven (Figure 4 and Table 3). 


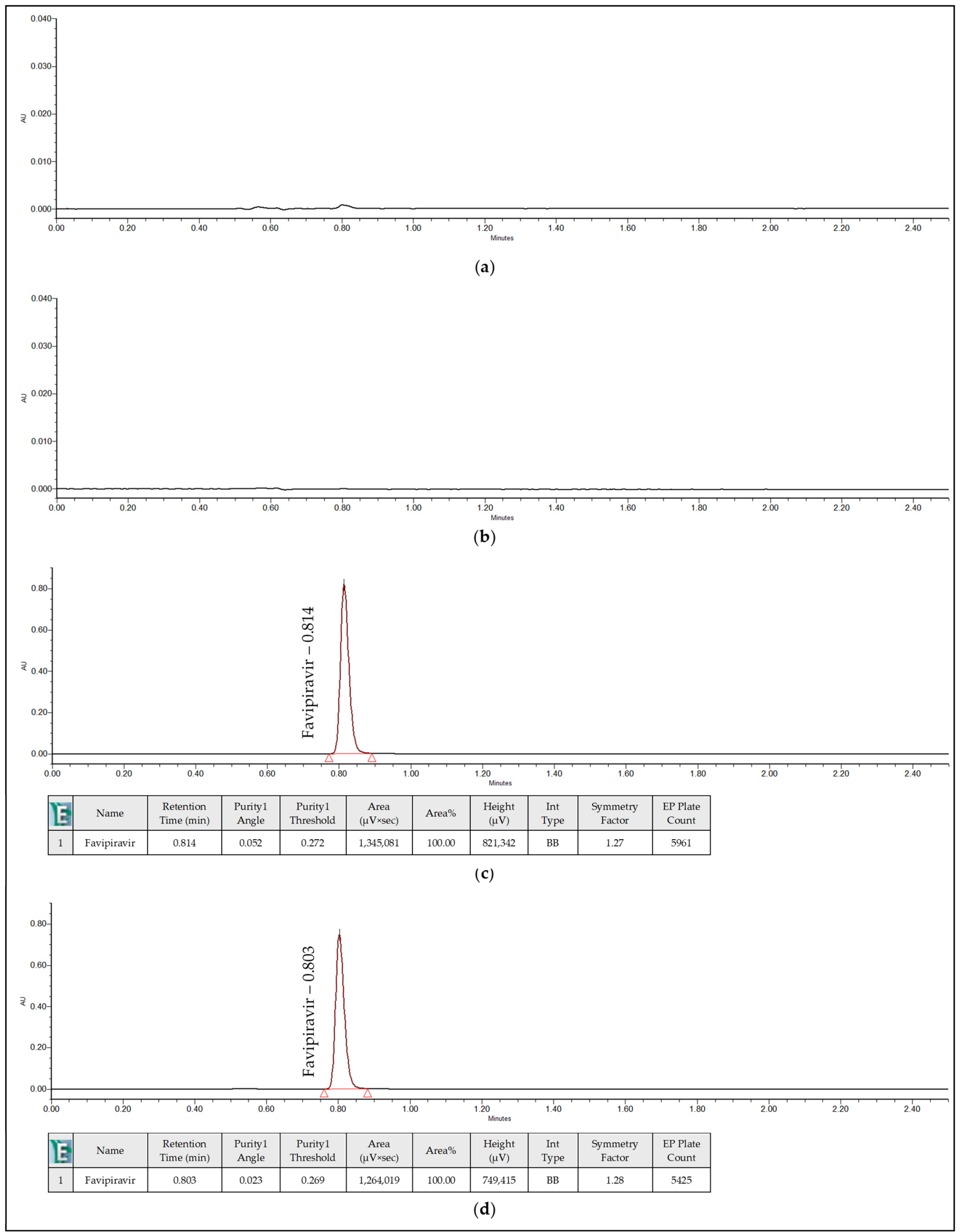

Figure 4. Selectivity Chromatogram: (a) Blank solution; (b) Placebo solution; (c) Standard solution; (d) Sample solution. 
Table 3. Results of Selectivity Study.

\begin{tabular}{ccccc}
\hline \multirow{2}{*}{ Name of Solution } & Retention Time (minutes) & \multicolumn{2}{c}{ Peak Purity } & \multirow{2}{*}{ Purity Criteria } \\
\cline { 3 - 4 } & & Purity Angle & Purity Threshold & \\
\hline Blank & No peaks & - & - & - \\
Placebo Solution & No peaks & - & - & - \\
Standard Solution & 0.814 & 0.052 & 0.272 & Pass \\
Sample Solution & 0.803 & 0.023 & 0.269 & Pass \\
\hline
\end{tabular}

\subsubsection{Linearity and Range}

The range of reliable quantification was set at the concentrations $0.044-0.44 \mathrm{mg} / \mathrm{mL}$. Peak areas and concentrations were subjected to least square regression analysis to calculate the regression equation. Slope, $y$-intercept, and correlation coefficient $(R)$ values were calculated. For the favipiravir linearity regression equation, $y=6,336,093 x+29,605$, and the correlation coefficient was found as $R=1.000(R>0.99)$ (Figure 5 and Table 4). The proposed method has been found as linear.

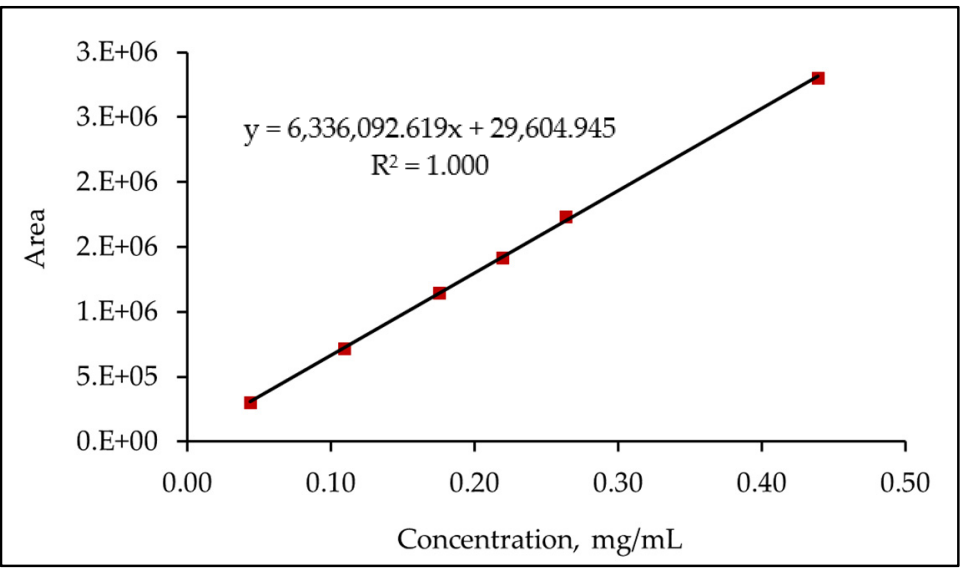

Figure 5. Linearity curve of favipiravir.

Table 4. Results of Linearity.

\begin{tabular}{ccc}
\hline Level $\%$ & Concentration $(\mathbf{m g} / \mathbf{m L})$ & Area \\
\hline 20 & 0.04394610 & 301,721 \\
50 & 0.10986525 & 718,160 \\
80 & 0.17578440 & $1,143,999$ \\
100 & 0.21973050 & $1,417,157$ \\
120 & 0.26367660 & $1,733,645$ \\
200 & 0.43946100 & $2,798,675$ \\
Corr. Coefficient & \multicolumn{3}{|c}{1.000} \\
Slope & \multicolumn{3}{c}{$29,604.992 .9159$} \\
y-intercept & \multicolumn{3}{c}{} \\
\hline
\end{tabular}

\subsubsection{System Precision}

The system suitability test was performed by injecting the standard solution containing $0.222 \mathrm{mg} / \mathrm{mL}$ in six replicates. The RSD\% of the peak area responses and retention times of analytes were determined. Additionally, the symmetry factor and theoretical plate count were calculated. The RSD \% of peak areas was found less than $2.0 \%$, theoretical plate count of peaks was above 2000, and symmetry factor of peaks was within $0.8-1.5$ (Table 5). The system precision of the method has been proven. 
Table 5. Results of System Suitability.

\begin{tabular}{ccccc}
\hline Sample No. & Symmetry Factor & Theorical Plate Count & Retention Time (min) & Area \\
\hline 1 & 1.06 & 6719 & 0.716 & $1,423,910$ \\
2 & 1.07 & 6710 & 0.717 & $1,435,439$ \\
3 & 1.06 & 6693 & 0.716 & $1,420,744$ \\
4 & 1.06 & 6682 & 0.716 & $1,430,521$ \\
5 & 1.06 & 6666 & 0.718 & $1,429,301$ \\
6 & 1.06 & 6701 & 0.717 & $1,429,755$ \\
Average & 1.06 & 6695 & 0.717 & $1,428,278$ \\
SD & 0.00 & 19.24 & 0.00 & 5203.5 \\
RSD $\%$ & 0.38 & 0.29 & 0.11 & 0.36 \\
\hline
\end{tabular}

\subsubsection{Method Precision-Repeatability}

The precision of the method was evaluated by analyzing the assay for six individual samples prepared from the same batch as per the proposed method. The average release $\%$ and RSD \% for the six sample preparations were calculated. The RSD\% was found as $1.99 \%$ (Table 6$)$. The RSD $\%(<5.0 \%)$ value indicates that the repeatability of the method has been proven.

Table 6. Results of repeatability.

\begin{tabular}{cc}
\hline Sample No. & Favipiravir Release $\%$ \\
\hline 1 & 103.1 \\
2 & 103.4 \\
3 & 99.9 \\
4 & 98.8 \\
5 & 102.7 \\
6 & 99.7 \\
Average & 101.3 \\
SD & 2.02 \\
RSD $\%$ & 1.99 \\
\hline
\end{tabular}

\subsubsection{Method Precision-Intermediate Precision}

The intermediate precision of the method was verified by conducting the precision study using different UHPLC system and different columns of the same make, by different analysts on different days. Six samples from the same batch were prepared and analyzed by the proposed method. The average release $\%$ and the RSD $\%$ for the two sets of data were calculated. The RSD\% was found as $2.49 \%$ (Table 7$)$. The overall RSD $\%(<5.0 \%)$ value indicates that the intermediate precision of the method has been proven.

Table 7. Results of intermediate precision.

\begin{tabular}{|c|c|c|}
\hline \multirow[b]{2}{*}{ Sample No. } & \multicolumn{2}{|c|}{ Favipiravir Release $\%$} \\
\hline & $\begin{array}{c}\text { Analyst-1 } \\
\text { Day-1 } \\
\text { Instrument-1 } \\
\text { Column-1 }\end{array}$ & $\begin{array}{c}\text { Analyst-2 } \\
\text { Day-2 } \\
\text { Instrument-2 } \\
\text { Column-2 }\end{array}$ \\
\hline 1 & 103.1 & 98.6 \\
\hline 2 & 103.4 & 97.8 \\
\hline 3 & 99.9 & 95.4 \\
\hline 4 & 98.8 & 103.3 \\
\hline 5 & 102.7 & 99.7 \\
\hline 6 & 99.7 & 100.3 \\
\hline Overall Average & \multicolumn{2}{|c|}{100.2} \\
\hline Overall SD & \multicolumn{2}{|c|}{2.49} \\
\hline Overall RSD\% & \multicolumn{2}{|c|}{2.49} \\
\hline F-Test of Significance & \multicolumn{2}{|c|}{0.05} \\
\hline$p$-value & \multicolumn{2}{|c|}{0.521} \\
\hline
\end{tabular}


The $p$-value for the F-test was found as 0.521 , and the alpha value was selected as 0.05 according to the $95 \%$ confidence interval. Since the $p$-value is greater than the alpha value, the results were found as compatible (Table 7).

\subsubsection{Accuracy}

The recovery $\%$ of the method was evaluated by performing recovery studies by spiking $10 \%, 100 \%$, and $120 \%$ standard to the placebo solution through the standard addition method. Individual recovery $\%$ and overall RSD \% were calculated. The recovery $\%$ for each level was found between $102.5 \%$ and $104.2 \%$, and the RSD \% was found as $0.53 \%$ (Table 8 ). The RSD $\%(<2.0 \%)$ value indicates that the accuracy of the method has been proven.

Table 8. Results of Accuracy.

\begin{tabular}{ccccc}
\hline Level $\%$ & Sample No. & Recovery $\%$ & Average & RSD $\%$ \\
\hline \multirow{3}{*}{10} & 1 & 103.4 & & \\
& 2 & 103.7 & 103.5 & 0.29 \\
3 & 1 & 103.3 & & \\
\multirow{2}{*}{100} & 2 & 103.9 & 103.6 & 0.67 \\
& 3 & 104.2 & & \\
\multirow{2}{*}{120} & 1 & 102.8 & 102.8 & 0.39 \\
& 3 & 102.5 & & 0.53 \\
\hline
\end{tabular}

\subsubsection{Robustness}

The robustness of the method was investigated by changing the instrumental conditions, such as wavelength, flow rate, column temperature, and stirring rate. The results are reported (Table 9). The method was found to be unaffected by small variations, and the robustness of the proposed method has been proven.

Table 9. Results of robustness.

\begin{tabular}{ccccc}
\hline Analysis Name & $\begin{array}{c}\text { Favipiravir } \\
\text { Release\% }\end{array}$ & $\begin{array}{c}\text { Retention } \\
\text { Time (min) }\end{array}$ & $\begin{array}{c}\text { Symmetry } \\
\text { Factor }\end{array}$ & $\begin{array}{c}\text { Theorical Plate } \\
\text { Count }\end{array}$ \\
\hline $\begin{array}{c}\text { Repeatability } \\
\text { Wavelength: } 223 \mathrm{~nm}\end{array}$ & 101.3 & 0.717 & 1.06 & 6695 \\
Wavelength: $227 \mathrm{~nm}$ & 100.0 & 0.712 & 1.06 & 6535 \\
Flow Rate: $0.3 \mathrm{~mL} / \mathrm{min}$ & 100.0 & 0.712 & 1.06 & 6541 \\
Flow Rate: $0.5 \mathrm{~mL} / \mathrm{min}$ & 99.3 & 0.948 & 1.05 & 7482 \\
Column Temperature: $33^{\circ} \mathrm{C}$ & 99.8 & 0.571 & 1.06 & 5553 \\
Column Temperature: $37^{\circ} \mathrm{C}$ & 99.9 & 0.715 & 1.06 & 6592 \\
Stirring Rate: $45 \mathrm{rpm}$ & 99.5 & 0.711 & 1.06 & 6556 \\
Stirring Rate: $55 \mathrm{rpm}$ & 88.5 & 0.714 & 1.06 & 6485 \\
\hline
\end{tabular}

\subsubsection{Solutions Stability}

In order to evaluate solution stability in the optimized dissolution medium, standard and sample solutions were stored at room temperature $\left(25^{\circ} \mathrm{C}\right)$ and were analyzed by UHPLC for $48 \mathrm{~h}$ at specified time intervals. The standard and sample solutions are found to be stable for $48 \mathrm{~h}$ as the similarity\% is in the range of $98.0-102.0 \%$ (Table 10).

Table 10. Results of Solution Stability.

\begin{tabular}{ccccc}
\hline \multirow{2}{*}{$\begin{array}{c}\text { Injection Time } \\
\text { (Hours) }\end{array}$} & \multicolumn{2}{c}{ Standard Solution } & \multicolumn{2}{c}{ Sample Solution } \\
\cline { 2 - 5 } & Area & Similarity\% & Area & Similarity\% \\
\hline Initial & $1,474,726$ & - & $1,462,137$ & - \\
24 & $1,466,496$ & 99.4 & $1,449,968$ & 99.2 \\
48 & $1,450,231$ & 98.3 & $1,433,548$ & 98.0 \\
\hline
\end{tabular}




\section{Conclusions}

The proposed dissolution method was developed and validated by the UHPLC method for Favipiravir $200 \mathrm{mg}$ Tablets according to the ICH guidelines [12]. The most suitable dissolution medium was selected as phosphate buffer with $\mathrm{pH} 6.8$ based on the solubility studies as QC medium. The suitable conditions of the dissolution test for Favipiravir $200 \mathrm{mg}$ Tablets were obtained using $900 \mathrm{~mL}$ of the dissolution medium containing phosphate buffer with $\mathrm{pH} 6.8$ maintained at $37.0 \pm 0.5^{\circ} \mathrm{C}$ with paddles (apparatus II) at $50 \mathrm{rpm}$ for $30 \mathrm{~min}$. The method was validated for various parameters, such as specificity, linearity and range, system precision, method precision (repeatability and intermediate precision), accuracy, robustness, and solution stability. All the parameters have met the acceptance criteria. The stability studies were performed, and the sample solutions were found to be stable for 2 days. The validated method was found selective, linear, precise, repeatable, accurate, and robust. Thus, the aforementioned analytical method with a short run time of $2.5 \mathrm{~min}$ can be successfully used for routine analysis of samples for Favipiravir $200 \mathrm{mg}$ Tablets.

Author Contributions: Conceptualization, Ö.G.; methodology, Ö.G., G.K. and M.G.; software, Ö.G. and E.A.; validation, Ö.G. and E.A.; formal analysis, Ö.G. and E.A.; investigation, G.K. and M.G.; resources, G.K. and M.G.; data curation, Ö.G.; writing-original draft preparation, Ö.G.; writingreview and editing, Ö.G., G.K. and M.G.; visualization, Ö.G. and G.K.; supervision, G.K. and M.G.; project administration, Ö.G., E.A., G.K. and M.G. All authors have read and agreed to the published version of the manuscript.

Funding: This research received no external funding.

Institutional Review Board Statement: Not applicable.

Informed Consent Statement: Not applicable.

Data Availability Statement: It will be supplied upon request.

Conflicts of Interest: The authors declare no conflict of interest.

\section{References}

1. Huang, C.; Wang, Y.; Li, X.; Ren, L.; Zhao, J.; Hu, Y.; Zhang, L.; Fan, G.; Xu, J.; Gu, X.; et al. Clinical features of patients infected with 2019 novel coronavirus in Wuhan, China. Lancet 2020, 395, 497-506. [CrossRef]

2. Du, Y.X.; Chen, X.P. Favipiravir: Pharmacokinetics and concerns about clinical trials for 2019-nCoV infection. Clin. Pharmacol. Ther. 2020, 108, 242-247. [CrossRef] [PubMed]

3. Li, G.; De Clercq, E. Therapeutic options for the 2019 novel coronavirus (2019-nCoV). Nat. Rev. 2020, 19, 149-150. [CrossRef] [PubMed]

4. Santosh, J.N.; Ramdas, A.P. Current progress, pharmacology and targeted drug development on SARS-CoV-2 pandemic. World J. Pharm. Pharm. Sci. 2020, 9, 1912-1918.

5. Frediansyah, A.; Tiwaric, R.; Sharund, K.; Dhamae, K.; Harapan, H. Antivirals for COVID-19: A critical review. Clin. Epidemiol. Glob. Health 2021, 9, 90-98. [CrossRef]

6. Nyarko, R.O.; Boateng, E.; Kahwa, I.; Boateng, P.O. A comparison analysis on remdesivir, favipiravir, hydroxychloroquine, chloroquine and azithromycin in the treatment of corona virus disease 2019 (COVID-19)-A Review. World J. Pharm. Pharm. Sci. 2020, 9, 121-133.

7. Yaghoubi, A.; Jamehdar, S.A.; Movaqar, A.; Milani, N.; Soleimanpour, S. An effective drug against COVID-19: Reality or dream? Expert Rev. Respir. Med. 2021, 15, 505-518. [CrossRef] [PubMed]

8. Joshi, S.; Parkar, J.; Ansari, A.; Vora, A.; Talwar, D.; Tiwaskar, M.; Patil, S.; Barkate, H. Role of favipiravir in the treatment of COVID-19. Int. J. Infect. Dis. 2021, 102, 501-508. [CrossRef] [PubMed]

9. Agrawal, U.; Raju, R.; Udwadia, Z.F. Favipiravir: A new and emerging antiviral option in COVID-19. Med. J. Armed Forces India 2020, 76, 370-376. [CrossRef] [PubMed]

10. Furuta, Y.; Komeno, T.; Nakamura, T. Favipiravir (T-705), a broad spectrum inhibitor of viral RNA polymerase. Proc. Jpn. Acad. Ser. B 2017, 93, 449-463. [CrossRef] [PubMed]

11. Taskeen, M.; Tirunagari, M.; Qureshi, H.K. Biorelevant and quality control dissolution method development and validation of quetiapine fumarate tablets. Acta Pharm. Sci. 2017, 55, 21-37. [CrossRef]

12. International Conference on Harmonization (ICH) of technical requirements for registration of pharmaceuticals for human use. In Validation of Analytical Procedures: Text and Methodology Q2(R1); ICH: Geneva, Switzerland, 2005. 
13. United States Pharmacopeia and National Formulary (USP43-NF38); Reagents and Reference Tables, Solutions, Buffer Solutions; United States Pharmacopeial Convention: Rockville, MD, USA, 2020.

14. European Pharmacopoeia, 10th ed.; 5.17.1 Recommendations on Dissolution Testing; 2020; Available online: https:/ /www.edqm. eu/en/european_pharmacopoeia_10th_edition (accessed on 26 October 2020).

15. United States Pharmacopeial Convention. United States Pharmacopeia and National Formulary (USP43-NF38); 1092, The Dissolution Procedure; United States Pharmacopeial Convention: Rockville, MD, USA, 2020.

16. European Medicines Agency. Committee for Medicinal Products for Human Use. Guideline on the Investigation of Bioequivalence. CPMP/EWP/QWP/1401/98 Rev.1 (01.2010); European Medicines Agency: Amsterdam, The Netherlands, 2010.

17. European Medicines Agency. Committee for Medicinal Products for Human Use. ICH M9 Guideline on Biopharmaceutics Classification System-Based Biowaivers. EMA/CHMP/ICH/493213/2018 (02.2020); European Medicines Agency: Amsterdam, The Netherlands, 2020.

18. Ploger, G.F.; Hofsass, M.A.; Dressman, J.B. Solubility determination of active pharmaceutical ingredients which have been recently added to the list of essential medicines in the context of the biopharmaceutics classification system-biowaiver. J. Pharm. Sci. 2018, 107, 1478-1488. [CrossRef] [PubMed]

19. European Medicines Agency. Committee for Medicinal Products for Human Use. Reflection Paper on the Dissolution Specification for Generic Solid Oral Immediate Release Products with Systemic Action. EMA/CHMP/CVMP/QWP/336031/2017 (08.2017); European Medicines Agency: Amsterdam, The Netherlands, 2017.

20. US Food and Drug Administration, Center for Drug Evaluation and Research. Guidance for Industry, Dissolution Testing of Immediate Release Solid Oral Dosage Forms; US Food and Drug Administration, Center for Drug Evaluation and Research: Rockville, MD, USA, 1997.

21. United States Pharmacopeial Convention. United States Pharmacopeia and National Formulary (USP43-NF38); 711, Dissolution; United States Pharmacopeial Convention: Rockville, MD, USA, 2020.

22. Johnson, L.A. Analysis of variance of parameter estimates: F tests and t tests. Anal. Biochem. 1992, 206, 195-201. [CrossRef]

23. Vaucher, L.C.; Paim, C.S.; Lange, A.D.; Schapoval, E.E.S. Development and validation of a dissolution test for telithromycin in coated tablets. Quim. Nova 2009, 32, 1329-1333. [CrossRef] 